\title{
Genesis Exploration of White Clays Deposited in Thimi Area of Kathmandu Valley
}

\author{
Madhusudan Dhakal ${ }^{1,2}$, Narendra Mani Adhikari ${ }^{3,5}$, Nirjan Duwal ${ }^{4}$, Susan Joshi ${ }^{3}$, Jagadeesh Bhattarai ${ }^{* 3}$ \\ ${ }^{1}$ Department of Chemistry, Tri-Chandra Multiple Campus, Tribhuvan University, Kathmandu, Nepal \\ ${ }^{2}$ University of Science and Technology of China, Hefei 230026, China \\ ${ }^{3}$ Central Department of Chemistry, IoST, Tribhuvan University, Kirtipur, Nepal \\ ${ }^{4}$ St. Xavier's College, affiliated with Tribhuvan University, Thapathali, Kathmandu, Nepal \\ ${ }^{5}$ Pacific Northwest National Laboratory, Richland, WA, USA (at present) \\ *Corresponding E-mail: bhattarai_05@yahoo.com; https://orcid.org/0000-0002-6662-396X \\ (Received: September 30, 2020; Revised: January 2, 2021; \& Accepted: January 2, 2021)
}

\begin{abstract}
The geological genesis of the Thimi-Sanothimi white clay deposits of Kathmandu Valley was explored employing mineralogical and chemical analyses in this research. For the study, two sample specimens of the clay having two types of particle size, i.e., about $<63 \mu \mathrm{m}$ (bulk) and $<2 \mu \mathrm{m}$ (fine), were separated with the help of standard sieve mesh which further modified using high-temperature heat, and $1 \mathrm{M} \mathrm{HCl}$ and $1 \mathrm{M} \mathrm{KCl}$ solution treatments. For the most part, both the clay fractions constituted of 2:1 type of vermiculite and mica (mainly of K-mica type) clay minerals with different feldspars and quartz phases as clay admixtures from the results of the mineralogical phase analysis. The chemical constituents of the clay particles with $<63 \mu \mathrm{m},<2 \mu \mathrm{m}$, and the $\mathrm{HCl}$-treated sample specimens confirmed the existence of a high quantity of $\mathrm{SiO}_{2}$ with comparatively low $\mathrm{Al}_{2} \mathrm{O}_{3}$ which indicates the presence of fewer amounts of the vermiculite and mica minerals comparatively with feldspars and quart admixtures in the analyzed white clay samples. Moreover, the clay sample contained a considerable quantity of $\mathrm{Fe}_{2} \mathrm{O}_{3}$ and $\mathrm{MgO}$ chemicals which are not favorable raw material constituents for good quality porcelains and white-wares products without refining and chemical-modifications. The present work could be the first step to explore its potentiality in various industrial sectors like table-ware, sanitary-ware, brick and tile ceramics, paper and pulp, petrochemical, pharmaceutical including environmental pollution controlling agents in Nepal.
\end{abstract}

Keywords: Elemental analysis, FTIR, K-mica, vermiculite mineral, XRPD

\section{Introduction}

Clays and clay minerals, originated from the Earth's surface rocks are formed [1], mostly by chemical weathering and/or hydrothermal activities for thousands of years [2]. They are inorganic materials having less than $2 \mu \mathrm{m}$ in equivalent spherical diameter particle size according to the mineralogists, although soil scientists and engineers define them as the earthen materials with $<4 \mu \mathrm{m}$ particle size without any significances about its mineralogical phases [3]. Besides, joint nomenclature committees (JNCs) of the Association Internationale Pourl' Etude des Argiles (AIPEA) and the Clay Minerals Society (CMS) defines the clay minerals as a class of hydrated phyllosilicates forming the fine-grained fraction of rocks, sediments which impart plasticity and harden when fired [4]. According to this definition, synthetic and fine materials are not considered natural clay minerals even though they may display the properties of plasticity and hardening on drying and firing [5]. The clay minerals are classified into major four groups based on the tetrahedral silicate $(\mathrm{T})$ and octahedral aluminate $(\mathrm{O})$ sheets such as; kaolin, montmorillonite/ smectite, mica, and chlorite [3]. In all types of clay minerals, the $\mathrm{T}$ and $\mathrm{O}$ sheets are stacked one above the other, exposing surfaces of oxygen and hydroxyl that can interact with each other by hydrogen bonding between the layers [6]. Details about these four groups of the inorganic clay minerals, their special properties, and applications are described elsewhere [7-12]. The clay minerals are continuously used since pre-historic times [13], depending on their basic properties of 
the physical, chemical, mineralogical compositions, and the structural so on $[14,15]$, because it becomes one of the fascinating topics for the mineralogists, industrialists, and the business entrepreneurs.

The phase composition, structure with large specific surface areas of the fine-sized clays results in distinct properties, which makes them effective properties to remove hazardous metals from the contaminated environments. Nowadays, natural clay minerals act as cost-effective natural scavengers for environmental pollutant remedies [16-20]. Moreover, the naturally deposited inorganic clays and clay minerals are practiced to use for the treatment of bacterial diseases from the earliest recorded history to recent years $[21,22]$. The uses of these natural clays in various industrial sectors and purposes depend mainly on their types and properties. In particular, all types of clay properties are affected mostly by their mineralogical phases, structures, and compositional structures which are frequently differ/deviate from their ideal compositional formula, because of isomorphous substitution (e.g., $\mathrm{Al}^{3+}$ for $\mathrm{Si}^{4+}$ in the tetrahedral sheet and $\mathrm{Mg}^{2+} / \mathrm{Fe}^{2+}$ for $\mathrm{Al}^{3+}$ in the octahedral sheet) in the layered-aluminosilicates structure of the clays and such substitution enhanced almost all kinds of their properties. Hence, it is necessary to characterize and carry out the rational analysis of such naturally deposited all types of clay minerals for identifying their conclusive possibilities in industrial sectors and for diverse uses [23].

Quantitative determination of mineralogical phases present in the clay minerals by combining quantitative chemical composition and qualitative analysis is known as rational (fractional) mineralogical analysis. The main purpose of the rational analysis of the clay minerals is to determine the rational composition, percentage of the different mineral compounds such as kaolin, montmorillonite/smectite, mica and chlorite group minerals, quartz, feldspars so on. It gives us a much better conception of the true character of the clay materials, although the process of rational analysis and calculation becomes much more complex. The rational analysis is furthermore useful only in connection with mixtures of high-grade clays, in which the variation of the ingredients can only be within comparatively narrow limits. It allows us for the prediction of the physicochemical and all possible technological properties of the clay minerals. For the purposes, both the qualitative and quantitative examination is frequently carried out to acquire the proportional amounts of clay minerals in both the bulk rock and the clay fractions. For the purposes, X-ray powder diffraction (XRPD) and Fourier transform infra-red (FTIR) techniques for the qualitative and the chemical element analysis for the quantitative analysis are frequently applied [24].

In the past, a few researchers studied the geological genesis [25-29], mineralogical [30-33], physicosintering [34-37], and ceramics [38-40] properties of clay minerals/soils of Nepal. A detailed study about the properties of porcelain raw materials deposited in Pachamane (Shivapuri conservation area of Kathmandu district) and Daman (Makawanpur district) areas of Nepal was carried out since the 1990s [9, 32, 41-43]. However, there are no detailed research works carried out yet on the geological genesis study of the natural white clay minerals deposited in the Thimi area of Bhaktapur, except their corrosive behavior to the buried-metallic pipelines [44,45], and adsorption characteristics [18]. In this context, the present work aimed to explore the geological genesis of the Thimi white clays based on their qualitative and quantitative data analyses. This study would be very useful for further explorations of other clay deposits in ceramic and other relevant industrial sectors in Nepal.

\section{Materials and Methods \\ Description of sampling site}

Kathmandu Valley looks like a shallow basin surrounded by Shivapuri, Nagarjun, Chandragiri, Pulchowki, and Nagarkot, which has typical lacustrine sediments which have attracted many geoscientists. Such sedimentary soil studies were mostly established on the recorded borehole data for diverse purposes [46]. The studies faced several important problems of stratigraphic division and nomenclature of the formations, mainly because of lack of information on the clay mineralogy of the surface to subsurface and insufficient description on the definition of each formation of Kathmandu valley. Only a few researchers have carried out the lithological and mineralogical evaluation of Kathmandu valley soils [30,31]. The Paleo-Kathmandu Lake is likely to have been initiated at around 2.1 Ma and to have been filled with black organic mud, the Kalimati clay [47]. However, lacks detailed studies carried out on the geo-mineralogy of white clay deposited between Arniko Highway and Sanothimi-Bhaktapur roadways areas of Bhaktapur district within Kathmandu valley of Nepal. The clay sample which is called "Kamero Mato" in Nepali means white soil and 'Takucha' in Newari language 
[8] occurs as a deposit over wide areas of the sampling site, and it is located between $27^{\circ} 40^{\prime} 30^{\prime \prime}-27^{\circ} 40^{\prime} 50^{\prime \prime} \mathrm{N}$ latitude and $85^{\circ} 23^{\prime} 40^{\prime \prime}-85^{\circ} 24^{\prime} 20^{\prime \prime}$ E longitude (Fig. 1). About two kg of clay sample that represents more or less all the clay deposited areas of the sampling site was collected to conduct this research work.

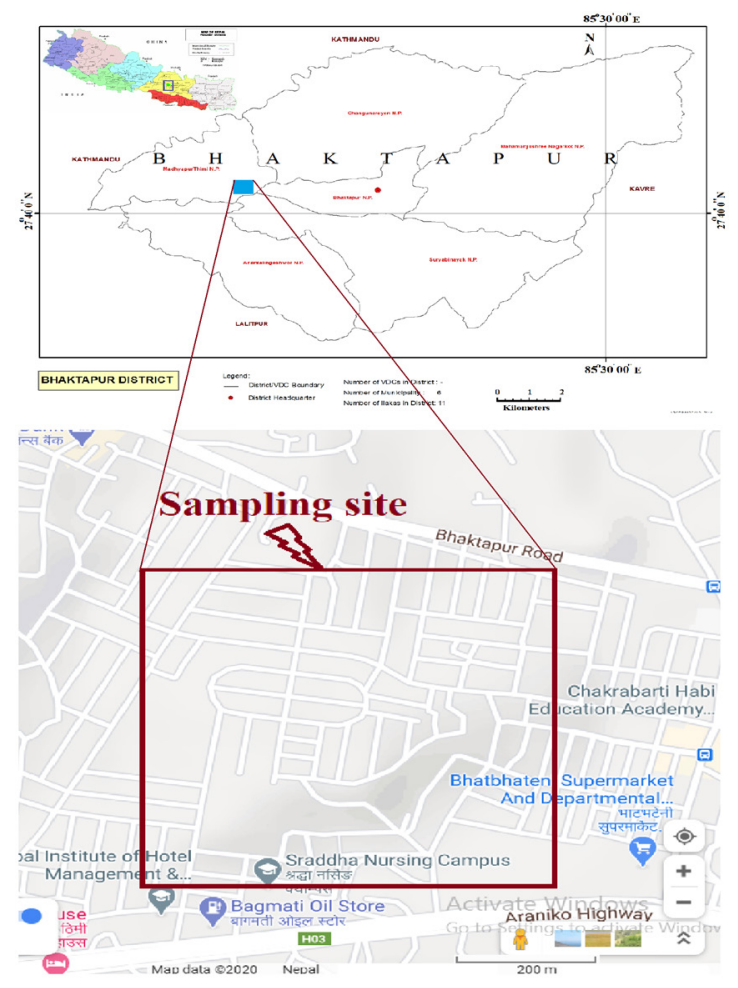

Figure 1: Clay sampling site located between SanothimiBhaktapur and Araniko Highway areas of Thimi

\section{Clay sample preparation}

The bulk sample (BCS) was prepared by using a US standard sieve, mesh no. 230 for the separation of $<63$ $\mu \mathrm{m}$ particles. The organic substance in the separated clay sample was treated with excess $\mathrm{H}_{2} \mathrm{O}_{2}(30 \%$ by volume) on a boiling water bath until effervescence ceased completely. The process was repeated $2 / 3$ times, washed with distilled water, and dried overnight on a hot oven at $110^{\circ} \mathrm{C}$ for obtaining the bulk clay particles. Moreover, fine clay minerals having $<2 \mu \mathrm{m}$ particles were separated using the elutriation process based on Stoke's law using "Calgon" as described elsewhere $[3,9]$ which is named as fine clay particles (FCP) hereafter. Heat treatment at different firing temperatures and chemical treatment using $1 \mathrm{M} \mathrm{HCl}$ and $1 \mathrm{M} \mathrm{KCl}$ solutions were accomplished for both the bulk and the fine clay samples.

Chemico-mineralogical analysis of clay sample

The chemical compositions of the bulk and the fine clay samples as well as the chemically treated fine clay samples were analyzed using the X-ray fluorescent method for $\mathrm{SiO}_{2}$, atomic absorption spectrophotometric method for $\mathrm{Fe}_{2} \mathrm{O}_{3}$ and $\mathrm{Al}_{2} \mathrm{O}_{3}$, EDTA-titration method for $\mathrm{CaO}$ and $\mathrm{MgO}$, a flame photometric method for $\mathrm{K}_{2} \mathrm{O}$ and $\mathrm{Na}_{2} \mathrm{O}$ and gravimetric method for ignition loss at $1000^{\circ} \mathrm{C}$. similarly, mineralogical phases and functional group identification present in the clay minerals were done using the recorded XRPD and the FTIR data, respectively. A D8 Advance Diffractometer (Bruker, Germany) with $\mathrm{CuK} \alpha$ radiation $(\lambda=0.15418$ $\mathrm{nm})$ at a scanning speed of $2 \% \mathrm{~min}$ in $2 \theta$ mode for recording XRPD patterns, and an IR Prestige-21 FTIR Spectrometer (Shimadzu, Japan) were used for such purposes. The identification of the clay minerals was made based on their basal spacing using the Joint Committee for Powder Diffraction Standards (JCPDS) files of clay minerals [48].

\section{Results and Discussion Chemical analysis}

Table 1 shows the estimated chemical compositions of the bulk and fine clays [39], and $\mathrm{HCl}$ treated fine clay samples. The amounts of $\mathrm{SiO}_{2}, \mathrm{Fe}_{2} \mathrm{O}_{3}, \mathrm{Na}_{2} \mathrm{O}$, $\mathrm{CaO}$ are considerably higher in the bulk clay sample as compare in both the fine clay samples without and with $1 \mathrm{M} \mathrm{HCl}$ treatment, while $\mathrm{K}_{2} \mathrm{O}, \mathrm{Al}_{2} \mathrm{O}_{3}$, and $\mathrm{MgO}$ are lower in the bulk sample than in fine and $\mathrm{HCl}$ treated clay samples. The decrease of $\mathrm{SiO}_{2}$ amount with the increase of $\mathrm{Al}_{2} \mathrm{O}_{3}$ in the fine clay sample than in the bulk indicating that the amount of clay minerals in the fine clay sample is more than in the bulk sample [39]. Similarly, the high amounts of $\mathrm{MgO}$ and $\mathrm{K}_{2} \mathrm{O}$ are found in the fine clay specimen than in the specimen with $<63 \mu \mathrm{m}$ particle size. This implies that the Kamerotar clay mineral with $<2 \mu \mathrm{m}$ average particle size constitutes mainly of $\mathrm{SiO}_{2}$ and $\mathrm{Al}_{2} \mathrm{O}_{3}$ with a considerable amount of $\mathrm{MgO}$. A considerable amount of $\mathrm{MgO}$ with more than $1 \%$, i.e., $1.86 \% \mathrm{Fe}_{2} \mathrm{O}_{3}$ in the fine clay minerals of the Kamerotar clay is not a suitable raw material for the industrial production of good quality porcelains or white wares without modifications and treatments. For example, the $\mathrm{HCl}$ treatment method might be best among others to remove the $\mathrm{Fe}_{2} \mathrm{O}_{3}$ from the sample, because $\mathrm{Fe}_{2} \mathrm{O}_{3}$ decreased with $1 \mathrm{M} \mathrm{HCl}$ treatment, as shown in Table 1. It is worthwhile to cite the certainty that a substantial amount of $\mathrm{Fe}_{2} \mathrm{O}_{3}$ and $\mathrm{K}_{2} \mathrm{O}$ in clay minerals ascribed to be iron-bearing muscovite, corresponding to K-mica [3]. 
Table 1: Chemical composition of the Thimi white clay specimens of Bhaktapur, Nepal

\begin{tabular}{llll}
\hline & \multicolumn{3}{c}{ Weight (\%) } \\
\cline { 2 - 4 } Oxides & Bulk** & Fine** & HCl-treated \\
\hline $\mathrm{SiO}_{2}$ & 66.50 & 60.18 & 61.33 \\
$\mathrm{Al}_{2} \mathrm{O}_{3}$ & 14.42 & 15.95 & 14.99 \\
$\mathrm{Fe}_{2} \mathrm{O}_{3}$ & 3.86 & 1.86 & 1.58 \\
$\mathrm{MgO}$ & 2.01 & 8.43 & 8.30 \\
$\mathrm{~K}_{2} \mathrm{O}$ & 2.16 & 2.64 & 2.43 \\
$\mathrm{Na}_{2} \mathrm{O}$ & 0.90 & 0.45 & 0.46 \\
$\mathrm{CaO}$ & 0.56 & 0.24 & 0.19 \\
$\mathrm{LOI}$ & 7.83 & 9.96 & 10.04 \\
$\mathrm{Misc}$ & 1.76 & 0.29 & 0.68 \\
\hline * at $1000^{\circ} \mathrm{C}^{* *}$ & ref $[39]$ & &
\end{tabular}

(1000 $\mathrm{C}, * * \operatorname{ref}[39]$

\section{Mineralogical phase analysis}

The XRPD analysis of clay minerals and ceramics is one of the effective methods for their mineralogical phase identification studies, although some circumstances make complications for precise phase identification from overlapping the peak values [49, 50]. Figure 2 shows the XRD patterns of the bulk, fine, and $\mathrm{HCl}$ treated clay samples. The reflection peaks at $1.449 \mathrm{~nm}, 1.00 \mathrm{~nm}, 0.72 \mathrm{~nm}, 0.290 \mathrm{~nm}, 0.256 \mathrm{~nm}$, $0.199 \mathrm{~nm}$, and $0.166 \mathrm{~nm}$ are assigned for vermiculite clay mineral which is observed in both the bulk and fine clay samples, as shown in Fig. 2.

The XRPD peaks at $1.00 \mathrm{~nm}, 0.720 \mathrm{~nm}, 0.256,0.199$ $\mathrm{nm}$, and $0.166 \mathrm{~nm}$ are more clearly observed in the fine clay sample than in the bulk clay sample. In contrast, the peak intensity at $1.449 \mathrm{~nm}$ for the fine clay sample is low as that of the bulk clay sample. Besides, the $\mathrm{K}_{2} \mathrm{O}$ content greater than 0.35 weight \% [51] in all analyzed clay samples suggests that Kamerotar clay is not pure vermiculite. It might contain mica, mica/ vermiculite interstratification that is in agreement with the XRPD results also (Fig. 2).

The presence of mica mineral in both bulk and fine clay samples is indicated by its 001 basal spacing at $1.00 \mathrm{~nm}$ with the second-order basal spacing (002) at $0.496 \mathrm{~nm}$. Apart from these, the peaks at $0.448 \mathrm{~nm}$, $0.334 \mathrm{~nm}$, and $0.256 \mathrm{~nm}$ are also assigned for mica minerals. Furthermore, it is important to identify whether the mica mineral is of muscovite (K-mica) or paragonite (Na-mica) type mineral. The peaks at $1.00 \mathrm{~nm}$ and $0.496 \mathrm{~nm}$ (i.e., not at $0.96 \mathrm{~nm}$ and 0.48 $\mathrm{nm}$ ) indicate that the Kamerotar clay sample contains mostly of a muscovite type of mica minerals. The same method of the identification of K-mica or Namica mineral was also used previously [52].

Strong reflection peaks at $0.427 \mathrm{~nm}, 0.334 \mathrm{~nm}$, $0.246 \mathrm{~nm}, 0.228 \mathrm{~nm}, 0.213 \mathrm{~nm}$, and $0.182 \mathrm{~nm}$ are assigned for quartz which is not a clay mineral

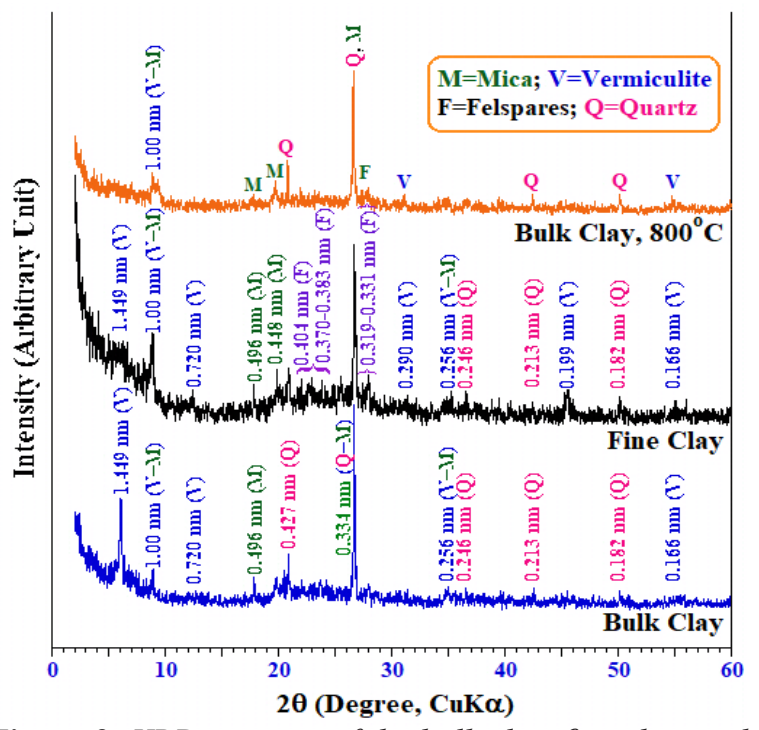

Figure 2: XRD patterns of the bulk clay, fine clay, and the bulk clay sample heated at $800^{\circ} \mathrm{C}$

although frequently present in $<2 \mu$ m clay fraction. The presence of quartz and mica in the clay samples might be the reason for showing a strong XRPD peak at $0.334 \mathrm{~nm}$. The $0.331 \mathrm{~nm}$ peak for mica minerals is generally overlapped with the quartz peak. The $2^{\text {nd }}$ most intense peak for the quart is confirmed from the $0.427 \mathrm{~nm}$. The intensity of the second most intense reflection peak at $0.427 \mathrm{~nm}$ for the quartz is observed in the fine clay sample. Less intense reflection peaks at $0.404 \mathrm{~nm}, 0.383-0.370 \mathrm{~nm}$, and $0.331-0.319 \mathrm{~nm}$ are attributed for feldspars, mostly of potassium-feldspar which is also supported by the chemical analysis data, as shown above in Table 1. More intense reflections of the feldspar in the fine clay sample than in the balk clay are due to an increase of $\mathrm{K}_{2} \mathrm{O}$ in fine clay particles than in bulk clay from in the chemical analysis data.

Furthermore, the presence of a $1.449 \mathrm{~nm}$ reflection peak is due to the vermiculite or/and chlorite minerals, because both these clay minerals have the basal reflection peak at around 1.4-1.5 $\mathrm{nm}$. The vermiculite clay mineral is usually identified based on its strong peak at $1.449-1.40 \mathrm{~nm}$, which collapsed to $1.00 \mathrm{~nm}$ after heat treatment of the bulk clay sample at $600^{\circ}$ $800^{\circ} \mathrm{C}$ for two hours, and the peak at $0.720 \mathrm{~nm}$ is also collapsed for the bulk clay sample (Figs. 2 and 3). It demonstrates that the interlayer $\mathrm{OH}^{-}$of vermiculite should be destroyed [53].

A similar effect of the complete collapsing of XRPD peaks at 1.445 and 0.720 in the bulk clay samples treated with $1 \mathrm{M} \mathrm{KCl}$ solutions, as shown in Fig. 4. The similar effects of $\mathrm{KCl}$ and heat treatments were 

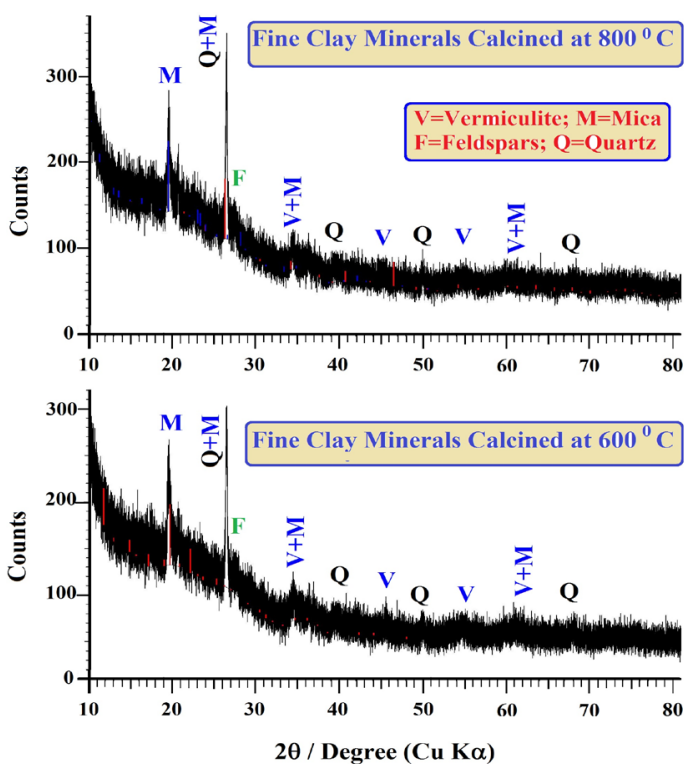

Figure 3: XRD patterns of the fine clay sample after heat treatment at $600^{\circ} \mathrm{C}, 800^{\circ} \mathrm{C}$ for 2 hours, and without the treatment for comparison

reported in previous studies for differentiating between vermiculite and chlorite minerals [54]. It reported that the collapse of the $1.45 \mathrm{~nm}$ basal spacing on heat treatment and relatively low intensity of the secondorder basal spacing at $0.72 \mathrm{~nm}$ pointed to a structure
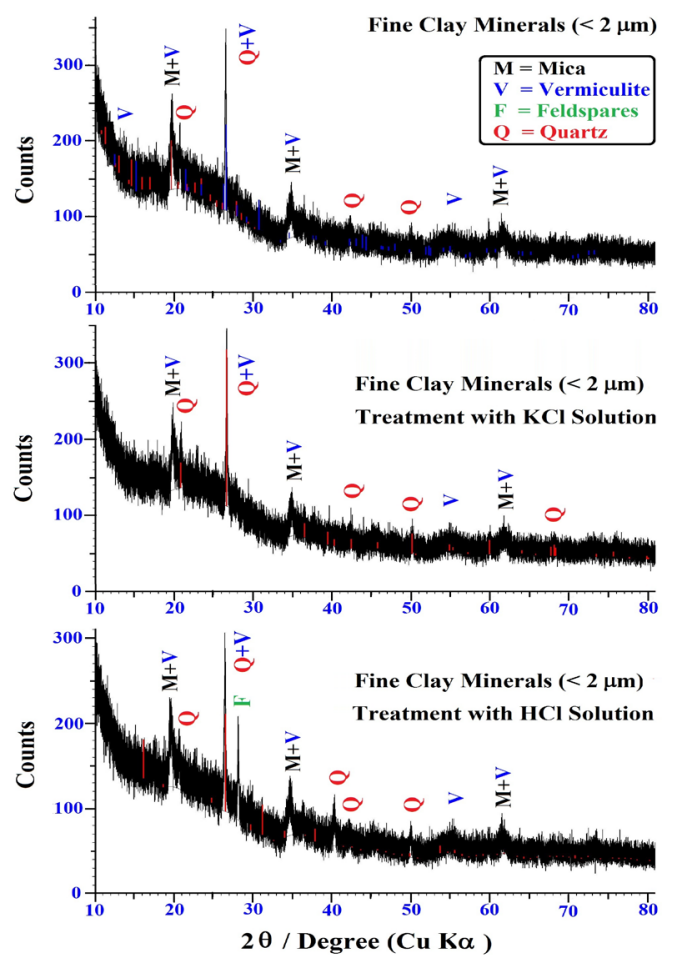

Figure 4: XRD patterns of the fine clay sample after chemical treatment in $\mathrm{HCl}, \mathrm{KCl}$ solutions, and without the treatment for comparison

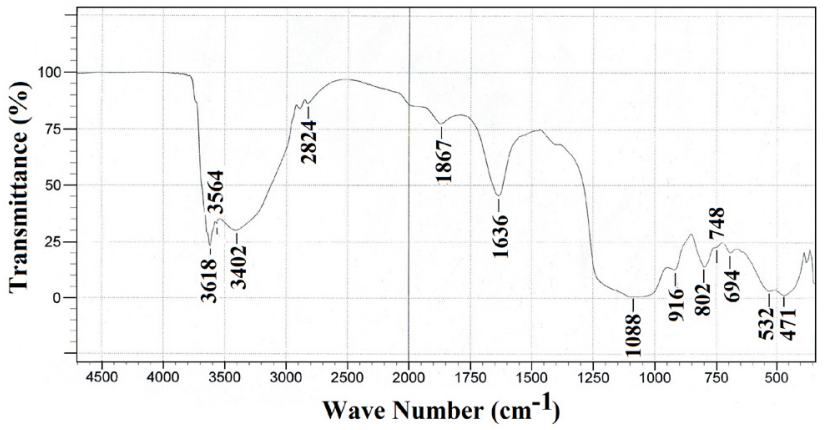

Figure 5: FTIR spectrum of the fine clay sample of Kamerotar area

more closely linked to vermiculite clay mineral than to the chlorite type mineral [55]. Consequently, the clay sample of the Kamerotar area consists of vermiculite clay minerals, not chlorite type. It is noteworthy to mention here that the muscovite type mica (i.e., K-mica) with paragonite (i.e., Na-mica) observed in single mica assemblages in middle-grade metamorphic rock, for which it reported the highest $\mathrm{Na} /(\mathrm{Na}+\mathrm{K})$ ratio, i.e., 0.31 [52]. However, the ratios of $\mathrm{Na} /(\mathrm{Na}+\mathrm{K})$ in both the bulk and fine clay samples were found to be 0.29 and 0.20 , respectively. These results revealed that the mica in the fine clay of Kamerotar is of muscovite. Consequently, major clay minerals identified in the Kamerotar clay sample of Bhaktapur, Nepal, are vermiculites, muscovite type of mica with feldspars and quartz as clay assessors chemical components from XRPD analysis.

FTIR spectroscopy is also one of the noted techniques for the confirmation of the mineralogical phases present in the clay samples, and it enables us to obtain sufficient information about individual minerals, noncrystalline admixtures, so on. It makes it possible to distinguish the different components of clay minerals $[56,57]$ and influences by a degree of crystalline order [58] and particle size of the natural clay materials [59]. Three bands between 3800-3000 $\mathrm{cm}^{-1}$ regions are observed for the fine clay (Fig. 5). A strong band at $3618 \mathrm{~cm}^{-1}$ attributed to $\mathrm{Al}-\mathrm{OH}-\mathrm{Al}$ with $\mathrm{Al}-\mathrm{Mg}-\mathrm{O}$ stretching vibrations. The existence of an interlayer - OH group between tetrahedral and octahedral sheets of the clay minerals gives an FTIR band near 3620 $\mathrm{cm}^{-1}$ [60]. Therefore, the FTIR peak at $3618 \mathrm{~cm}^{-1}$ for both the fine clay minerals associated with the inner hydroxyl group present in the clay samples of Kamerotar. The peak at $3564 \mathrm{~cm}^{-1}$ is mostly of the $\mathrm{FeFeOH}$ grouping in the octahedral sheets of the minerals that are also consistent with previous reports [61]. Besides, the broad peak near $3400 \mathrm{~cm}^{-1}$ indicated 
the stretching $\mathrm{H}-\mathrm{O}-\mathrm{H}$ vibrations [59], and hence the broad peak at $3402 \mathrm{~cm}^{-1}$ is considered to interlayer hydroxide in Kamerotar fine clay sample.

It is meaningful to cite here that the vermiculites showed the $-\mathrm{OH}$ bending vibration mode at 1635 $\mathrm{cm}^{-1}$ [56] that is in good agreement with the band of $\mathrm{H}-\mathrm{O}-\mathrm{H}$ stretching vibration of the present clay sample. Consequently, it can sum up that the Kamerotar white clay consists of vermiculite type clay minerals. Furthermore, only one broad and complex $\mathrm{Si}-\mathrm{O}$ stretching band at $1088 \mathrm{~cm}^{-1}$ is observed in the FTIR spectrum of the fine clay sample, and it might be because quartz was also assigned to the $\mathrm{Si}-\mathrm{O}$ stretching at $1080 \mathrm{~cm}^{-1}[62]$. The absorption bands at $802 \mathrm{~cm}^{-1}, 748 \mathrm{~cm}^{-1}$, and $471 \mathrm{~cm}^{-1}$ are due to the bending vibration of $\mathrm{Si}-\mathrm{O}-\mathrm{Si}$ linkage in quartz [63]. These results are consistent with the XRPD analysis (Fig. 2), as described above. FTIR bands near 694 $\mathrm{cm}^{-1} 532 \mathrm{~cm}^{-1}$ are due to the $\mathrm{Al}-\mathrm{O}-\mathrm{Si}$ and the $\mathrm{Mg}-\mathrm{O}$ linkages, respectively. The $\mathrm{Al}_{2} \mathrm{O}$ bending band of the clay minerals near $918 \mathrm{~cm}^{-1}$ arises from vibrations of the inner $-\mathrm{OH}$ group of the clay minerals [64].

\section{Conclusions}

Major clay minerals identified in the Thimi white clays are vermiculite, micas, feldspars, and quartz-based on the chemical, XRD, and FTIR analyses. Considerable amounts of $\mathrm{Fe}_{2} \mathrm{O}_{3}$ and $\mathrm{K}_{2} \mathrm{O}$ present in the clay sample is attributed to be iron-bearing muscovite, analogous to K-mica. Furthermore, the considerable amounts of $\mathrm{Fe}_{2} \mathrm{O}_{3}$ and $\mathrm{MgO}$ contained in both the fine and bulk clay samples compared to the standard clay raw materials used for the porcelain productions indicated that these clay deposits are not suitable raw materials for a good quality of the white-ware productions without modifications and purification, for example, $\mathrm{HCl}$ treatments. Instead, it may be used as a suitable adsorbent for removable of toxic ions or compounds from contaminated water.

\section{Acknowledgments}

MD and NMA are thankful to The University Grants Commission-Nepal, Bhaktapur for providing the Masters' Thesis Supports to MD and NMA to carry out this research work. The authors are thankful to Professor Dr. Lalu Prasad Paudel, Tribhuvan University, and Nepal Academy of Science and Technology (NAST), Lalitpur for their valuable help in XRD and FTIR measurements.

\section{References}

1. C. E. Weaver and L. D. Pollard, The Chemistry of Clay Minerals, Elsevier Scientific Pub. Co.,
Amsterdam/New York, 1973, p. 213.

2. B. B. Velde and A. Meunier, The Origin of Clay Minerals in Soils and Weathered Rocks, SpringerVerlag, Heidelberg, Berlin, 2008, p. 406.

3. W. E. Worrall, Clay and Ceramic Raw Materials, $2^{\text {nd }}$ edition, Elsevier Applied Science Publishers, London/New York, 1986, 27-47 \& 180-185.

4. S. Guggenheim and R. T. Martin, Definition of clay and clay mineral, Joint report of the AIPEA nomenclature and CMS nomenclature committee, Clays and Clay Minerals, 1995, 43(2), 255-256. (DOI:10.1346/CCMN.1995.0430213)

5. A. Awasthi, P. Jadhao and K. Kumari, Clay nanoadsorbent: structures, applications and mechanism for water treatment, SN Applied Sciences, 2019, 1, 1076 (pp. 21). (DOI:10.1007/s42452-019-0858-9)

6. R. E. Grim, Clay Mineralogy, $1^{\text {st }}$ edition, McGrawHill, New York, 1953, pp. 348-360.

7. S. Gu, X. Kang, L. Wang, E. Lichtfouse and C. Wang, Clay mineral adsorbents for heavy metal removal from wastewater: a review, Environmental Chemistry Letters, 2018, 17(2), 629654. (DOI:10.1007/s10311-018-0813-9)

8. N. Duwal, M. Dhakal, N. M. Adhikari, S. Joshi and J. Bhattarai, Characterization of Kamerotar clays of Madhyapur Thimi Municipality of Bhaktapur, Nepal, Journal of University Grants CommissionNepal, 2015, 4(1), 54-66. Retrieved from (http:// jugc.edu.np/index.php/JUGC/article/view/57)

9. J. Bhattarai and K. Okada, Characterization of clay raw materials in Nepal and applicability for porcelain raw materials, Clay Science, 1992, 8, 392402. (DOI:10.11362/jcssjclayscience1960.8.393)

10. M. Massaro, C. G. Colletti, G. Lazzara, and S. Riela, The use of some clay minerals as natural resources for drug carrier applications. Journal of Functional Biomaterials, 2018, 9(4), 58. (DOI:10.3390/jfb9040058)

11. J. D. D. Moraes, S. R. A. Bertolino, S. L. Cuffini, D. F. Ducart, P. E. Bretzke and G. R. Leonardi, Clay minerals: properties and applications to dermo-cosmetic products and perspectives of natural raw materials for therapeutic purposes- a review, International Journal of Pharmaceutics, 2017, 534(1-2), 213-219. (DOI:10.1016/j. ijpharm.2017.10.031)

12.S. Mukherjee, Clays: Industrial applications and their determinants, In The Science of Clays, Springer, Dordrecht, 2013, Chapter-7, 113-122. (DOI:10.1007/978-94-007-6683-9_7) 
13.W. D. Kingery, Ancient technology to modern science in ceramics and civilization, American Ceramic Society, 1985, 1, 1-25.

14.H. H. Murray, Traditional and new applications for kaolin, smectite, and palygorskite: a general overview. Applied Clay Science, 2000, 17(5-6), 207-221. (DOI:10.1016/S0169-1317(00)00016-8)

15.H. H. Murray, Overview- clay mineral applications, Applied Clay Science, 1991, 5(5-6), 379-395. (DOI:10.1016/0169-1317(91)90014-Z)

16. A. Alshameri, X. Wei, H. Wang, Y. Fuguo, X. Chen, H. He, C. Yan and F. Xu, A review of the role of natural clay minerals as effective adsorbents and an alternative source of minerals, In K.S. Essa (Ed.), Minerals, IntechOpen, 2019, Chapter-3, 5963. (DOI:10.5772/intechopen.87260)

17. M. K. Uddin, A review on the adsorption of heavy metals by clay minerals, with special focus on the past decade, Chemical Engineering Journal, 2017, 36, 438-462. (DOI:10.1016/j.cej.2016.09.029)

18. N. Duwal, S. Joshi and J. Bhattarai, Study on the removable of methylene blue by calcinedKamerotar clays as an eco-friendly low-cost adsorbent, International Journal of Advanced Research in Chemical Science, 2016, 3(11), 1-8. (DOI:10.20431/2349-0403.0311001)

19. S. Ismadji, F. E. Soetaredjo and A. Ayucitra, Natural clay minerals as environmental cleaning agents, In Clay Materials for Environmental Remediation, Springer, Berlin, 2015, 5-17. (DOI:10.1007/978-3-319-16712-1_2)

20. J. Bhattarai, Adsorption of indigo-carmine dye on kaolin in aqueous medium, Tribhuvan University Journal, 1994, 17(1), 10-19.

21. A. Stavitskaya, S. Batasheva, V. Vinokurov, G. Fakhrullina, V. Sangarov, Y. Lvov and R. Fakhrullin, Antimicrobial applications of clay nanotube-based composites, Nanomaterials (Basel), 2019, 9(5), 708 (pp. 20). (DOI:10.3390/ nano9050708)

22. S. E. Haydel, S. C. M. Remenih and L. B. Williams, Broad-spectrum in vitro antibacterial activities of clay minerals against antibiotic-susceptible and antibiotic-resistant bacterial pathogens, The Journal of Antimicrobial Chemotherapy, 2008, 61(2), 353-361. (DOI:10.1093/jac/dkm468 )

23. T. Vakalova, V. Pogrebenkov, V. Vereshagin, T. Khabas and I. Revva, Optimising rational chemical analysis for quantitative determination of the composition of clay in soils, Applied Clay
Science, 2018, 163, 153-163. (DOI:10.1016/j. clay.2018.07.014)

24. J. Srodon, Identification and quantitative analysis of clay minerals. In F. Bergaya, B. K. G. Thang and G. Lagaly (Eds), Developments in Clay Science (eds., 2006, Chapter 12.2, 765-787. (DOI:10.1016/ S1572-4352(05)01028-7)

25. K. P. Kaphle, Mineral Resources of Nepal and Their Present Status, Nepal Geological Society, Kathmandu, Nepal, 2020, 1-15.

26. B. Neupane andD.P. Adhikari, Role of clayminerals in the occurrence of landslides along NarayangarhMugling Highway section, central Nepal, Journal of Nepal Geological Society, 2011, 43 (Sp. Issue), 301-308. (https://www.researchgate.net/ publication/282073426) [accessed Sept. 26, 2020]

27. J. Bhattarai, Genesis of clay deposit in Panchamane area of Kathmandu, Nepal, Journal of Nepal Geological Society, 2001, 24 (Sp. Issue), 20-21.

28. J. Stöcklin, Geology of Nepal and its regional frame, JournalofGeological Society London, 1980, 137(1), 1-34. (DOI:10.1144/gsigs.137.1.0001)

29. J. Stöcklin and K. D. Bhattarai, Geology of Kathmandu Area and Central Mahabharat Range, Nepal, In: Himalaya Report (unpublished), Department of Mines and Geology, Kathmandu, Nepal, 1977, pp. 86.

30. M. R. Paudel, Lithological and mineralogical variations: Indicator of provenance and paleoenvironmental change of the Kathmandu Basin fill sediments, Nepal, In: Sixth Nepal Geological Congress on Geology, Natural Resources, Infrastructures, Climate Change and Natural Disasters, November 15-17, Kathmandu, Nepal, 2010.

31. S. M. Rai, B. N. Upreti, S. Guillot, A. Pecher and P. L. Fort, Mineral chemistry (biotite, muscovite, garnet, and plagioclase) in the Kathmandu and Gosainkund regions, central Nepal Himalaya, Journal of Nepal Geological Society, 2004, 30, $55-66$.

32. J. Bhattarai and K. Okada, Physico-chemical investigation of kaolin minerals of Panchmane area in Nepal, Journal of Nepal Chemical Society, 1999, 17-18, 12-21.

33. J. Bhattarai, Chemico-mineralogical investigation of chlorite minerals in Nepal and their firing properties, Tribhuvan University Journal, 1998, 21(1), 1-12.

34. Y. P. Chapagain, S. Sapkota, D. B. Ghale, N. B. 
Bohara, N. Duwal and J. Bhattarai, A case study on mineralogy and physico-mechanical properties of commercial bricks produced in Nepal, SN Applied Sciences, 2020, 2, 1856 (14 pp). (DOI:10.1007/ s42452-020-03535-y)

35. N. B. Bohara, D. B. Ghale, Y. P. Chapagain, N. Duwal and J. Bhattarai, Effect of firing temperature on physico-mechanical properties of contemporary clay brick productions in Lalitpur (Nepal), Bangladesh Journal of Scientific and Industrial Research, 2020, 55(1), 43-53. (DOI:10.3329/bjsir. v55i1.46731)

36. P. Budhathoki, N. Duwal and J. Bhattarai, Investigation on physico-sintering and mechanical properties of clay tiles available in Kathmandu Valley of Nepal, Asian Journal of Chemistry, 2018, 30(11), 2515-2530. (DOI:10.14233/ ajchem.2018.21509)

37. N. B. Bohara, L. B. Bhat, D. B. Ghale, N. Duwal and $J$. Bhattarai, Investigation of the firing temperature effects on clay brick sample; part-I: mineralogical phase characterization, Bibechana, 2018, 16, 122-130. (DOI:10.3126/bibechana. v16i0.21319

38. J. Bhattarai, Investigation on the mineralogical phase of ancient brick samples of Kathmandu valley (Nepal) using XRD and FTIR analysis, Rasayan Journal of Chemistry, 2019, 12(2), 402408. (DOI:10.31788/RJC.2019.1224034)

39. J. Bhattarai, D. B. Ghale, Y. P. Chapagain, N. B. Bohara and N. Duwal, Study on the physical and mechanical properties of ancient clay brick samples of Kathmandu valley, Nepal, Tribhuvan University Journal, 2018, 32(2), 1-18. (DOI:10.3126/tuj.v32i2.24699)

40. P. Budhathoki, P. Paudal, R. R. Oli, N. Duwal and J. Bhattarai, Assessment on the characterization of mineralogical phase of ceramic tiles available in Kathmandu valley (Nepal) using XRD and FTIR analyses, International Journal of Applied Science and Biotechnology, 2018, 6(3), 238-243. (DOI:10.3126/ijasbt.v6i3.21171)

41.J.Bhattarai and B. R. Bhattarai, X-ray photoelectron spectroscopy investigation on sintered-bodies of porcelain raw materials of Nepal, Analytical Sciences (supplement), 2001, 17, a361-a363. (DOI:10.1489/analscisp.17asia.0.a361.0)

42. J. Bhattarai and K. Okada, The effect of wet ball milling on physico-mineralogical and sintering properties of porcelain raw materials, Nepal
Journal of Science and Technology, 2000, 2, 5-16. (https://www.nast.org.np/njst/index.php/njst/ article/view/29)

43. J. Bhattarai and K. Okada, The effect of heating rate and soaking time on sintering behavior of some ceramic clay minerals, Journal of Nepal Chemical Society, 1993, 12, 46-54. (https://www. researchgate.net/publication/344387804)

44. Y. R. Dhakal, K. P. Dahal and J. Bhattarai, Investigation on the soil corrosivity towards the buried water supply pipelines in Kamerotar town planning areas of Bhaktapur, Nepal, Bibechana, 2014, 10, 82-91. (DOI:10.3126/bibechana. v10i0.8454)

45. K. P. Dahal, D. KC and J. Bhattarai, Study on the soil corrosivity towards the buried water supply pipelines in Madhyapur Thimi Municipality, Bhaktapur, Bibechana, 2014, 11, 94-102. (DOI:10.3126/bibechana.v11i0.10387)

46. Y. R. Paudyal, R. Yatabe, N. P. Bhandary and R. K. Dahal, Basement topography of the Kathmandu Basin using microtremor observation, Journal of Asian Earth Sciences, 2013, 62, 627-637. (DOI:10.1016/j.jseaes.2012.11.011)

47. R. Fujii and H. Sakai, Paleoclimatic changes during the last 2.5 myr recorded in the Kathmandu Basin, Central Nepal Himalayas. Journal of Asian Earth Sciences, 2002, 20(3), 255-266. (DOI:10.1016/ S1367-9120(01)00048-7)

48. JCPDS, Joint Committee on Powder Diffraction Standards, USA, 1999.

49. Z. Zhou, D. Liu, H. Bu, L. Deng, H. Liu, P. Yuan, P. Du and H. Song, XRD-based quantitative analysis of clay minerals using reference intensity ratios, mineral intensity factors, Rietveld, and full pattern summation methods: A critical review, Solid Earth Sciences, 2018, 3(1), 16-29. (DOI:10.1016/j. sesci.2017.12.002)

50. I. G. Berry, Selected Powder Diffraction Data for Mineralogy, Joint Committee on Powdered Diffraction Standard, Swanshmore, USA, 1974.

51. A. Justo, C. Maqueda, J. L. Perez-Rodriguez and E. Morillo, Expansibility of some vermiculites, Applied Clay Science, 4(5-6): 509-519 (1989). (DOI:10.1016/0169-1317(89)90027-6)

52. C. V. Guidotti, Mica in metamorphic rocks, In Micas (ed. S.W. Bailey), Review of Mineralogy, Mineralogical Society of America, USA, 1984, Chapter 13, 257-468.

53. K. Yin, H. Hong, Y. Pan and Z. I. Liu, Mineralogy 
and genesis of mixed-layer illite-vermiculite in the homogeneous red soil and the net-like red soil of Xuancheng, China, Applied Ecology and Environmental Research, 2017, 15(3), 675-686. (DOI:10.15666/aeer/1503 675686)

54. H. N. Khoury and W. El -Sakka, Mineralogical and industrial characterization of the Batn El-Ghoul clay deposits, southern Jordan, Applied Clay Sciences, 1986, 1(4), 321-351. (DOI:10.1016/0169-1317(86)90009-8)

55. M. Wang, L. Liao, X. Zhang, Z. Li, Z. Xai and W. Cao, Adsorption of low-concentration ammonium onto vermiculite from Hebei Province, China, Clays and Clay Minerals, 2011, 59(5), 459-465. (DOI:10.1346/CCMN.2011.0590503)

56. J. Madejova, W. P. Gates and S. Petit, IR spectra of clay minerals, Developments in Clay Science, 2017, 8, 107-149. (DOI:10.1016/B978-0-08100355-8.00005-9)

57. N. N. Bukalo, G. I. E. Ekosse, J. O. Odiyo and J. S. Ogola, Fourier transforms infrared spectroscopy of clay size fraction of cretaceous- tertiary kaolin in the Douala sub-basin, Cameroon. Open Geoscience, 2017, 9(1), 407-418. (DOI:10.1515/ geo-2017-0031)

58. A. N. Lazarev, The dynamics of crystal lattices, In V.C. Framer (Ed.), The Infrared Spectra of Minerals, Mineralogical Society, London, 1974, pp. 69-86.
59. V. C. Farmer and J. D. Russell, Effect of particle size and structure on the vibrational frequencies of layer silicates, Spectrochimica Acta, 1966, 22(3), 389-398. (DOI:10.1016/0371-1951(66)80069-3)

60. J. Madejova, FTIR Techniques in clay mineral studies, Vibrational Spectroscopy, 2003, 31(1), 1-10. (DOI:10.1016/S0924-2031(02)00065-6)

61. J. D. Russel and A.R. Fraser, In M.J. Wilson (Ed.), Clay Mineralogy: Spectroscopic and Chemical Determination Methods, Chapman \& Hall, London, UK, 1994, 11-67. (DOI:10.1007/978-94011-0727-3_2)

62. J. Madejova and P. Komadel, Baseline studies of the clay minerals society source clays: Infrared methods, Clays and Clay Minerals, 2001, 49(5), 410-432. (DOI:10.1346/CCMN.2001.0490508)

63. H. H. W. Moenke, Silica, the three-dimensional silicates, borosilicates and beryllium silicates, In V.C. Framer (Ed.), Infrared Spectra of Minerals, Monograph 4, Mineralogical Society, London, UK, 1974, Chapter 16, 365-380.

64. B. B. Zviagina, V. A. Drits and O. V. Dorzhieva, Distinguishing features and identification criteria for K-dioctahedral $1 \mathrm{M}$ micas (illitealuminoceladonite and illite-glauconite-celadonite series) from middle-infrared spectroscopy data, Minerals, 2020, 10, 153. (DOI:10.3390/ $\min 10020153$ ) 